\title{
Perception and Actual Experiences of Sexual Harassment in Clinical Placement among Physical Therapy College Students
}

JoonHee Lee

Department of Physical Therapy, College of Health and Medical Science, Cheongju University, Cheongju, Korea

Purpose: This study examined the level of self-esteem and awareness of sexual harassment among college students majoring in physical therapy to discover the status of sexual harassment and the types of and responses to sexual harassment at clinical training sites. Methods: The study participants included 195 college students majoring in physical therapy in Gyeonggi and Chungcheong provinces, who responded fully to the survey questionnaire. The data were prepared through self-reporting on a structured questionnaire and collected from September to November 2018.

Results: The difference in the mean value of self-esteem was evident between the two groups investigated. The most common types of sexual harassment were verbal, visual, and physical. The types of damage reported by the participants were emotional, physical, and social. The group of participants who experienced sexual harassment had a high rate of avoidance, while the group of participants who did not experience sexual harassment exhibited a high rate of coping.

Conclusion: The incidence of verbal sexual harassment was reported to be significantly higher, and the emotional damage was the most serious. Students should be provided with more specific and realistic preventive education or countermeasures so they can respond more proactively to real situations.

Keywords: Physical therapy, Sexual harassment, Self-esteem

서 론

성희롱(sexual harassment)이란 업무, 고용, 그 밖의 관계에서 공공기관 의 종사자, 사용자 또는 근로자가 그 직위를 이용하거나 업무 등과 관 련해, 성적 언동 등으로 성적 굴욕감 또는 혐오감을 느끼게 하거나 성 적 언동 그 밖의 요구 등에 대한 불응을 이유로 고용상의 불이익을 주는 것을 말한다. 성희롱은 사회적으로 불평등한 구조 속에서 발생 되는 성차별과 관련된 문제이며, 우월한 위치에 있는 사람이 종속된 자에게 원하지 않는 성적인 언행을 할 때 일어날 수 있다. 최근 보고 에 따르면 보건의료분야 종사자의 상당수가 환자 및 보호자 등으로 부터 성희롱을 경험했다고 하였다. ${ }^{2}$ 특히 물리치료사가 시행하는 도 수치료, 통증치료, 신경계 치료 등의 행위는 환자와 긴밀한 신체 접촉 이 동반되어, 성희롱이나 추행이 더 빈번하게 발생될 수 있다. 미국물 리치료사협회에서 시행한 설문연구에 의하면 응답한 물리치료사의 $86 \%$ 는 치료과정 중에 환자의 성적행위를 목격했고, 응답자의 $63 \%$ 는

Received Dec 31, 2019 Revised Feb 10, 2020

Accepted Feb 20, 2020

Corresponding author JoonHee Lee

E-mail pieta2000@hanmail.net
성희롱을 경험했다고 하였다. 그럼에도 불구하고 성희롱 발생시 대 처하는 방법을 교육받은 응답자는 3 분의 1 도 되지 않았다. 또 다른 연구에 의하면 설문에 응답한 물리치료사와 물리치료학과 학생 $80.9 \%$ 는 환자의 부적절한 성적 행위를 목격하였고, 학생 3 분의 1 이 강 제적인 성적 접촉과 고의적인 성적 노출 등 심각한 성희롱을 경험했 다고 응답하였다. 임상실습에 참여하는 학생들은 실습 현장의 권력 구조 측면에서 의료인들에 비해 연령이 낮고 직무에 대한 경험이나 훈련이 부족하여, 임상실습 기간 동안 약자의 위치에 있기 때문에 성 희롱의 피해에 노출되기 쉽다. ${ }^{5}$ 비슷한 예로 간호학과 학생들이 간호 사에 비해 임상경험과 기술이 부족하고 대상자와의 잦은 접촉으로 인해 간호사를 비롯한 의료인들, 환자나 보호자의 무례한 행동에 노 출되기 쉽다고 하였다. ${ }^{6}$

선행연구들에 의하면 성희롱이 발생하였을 때 이를 인식하고 대처 하는 것과 관련하여 자아존중감을 주요 변수로 보고하였다. $7 ., 12$ 자아 존중감이란 자신을 긍정적으로 평가하고 자신의 중요성과 잠재력,
Copylight (C)2020 The Korean Society of Physical Therapy

This is an Open Access article distribute under the terms of the Creative Commons Attribution Non-commercial License (https:// creativecommons.org/license/by-nc/4.0.) which permits unrestricted non-commercial use, distribution, and reproduction in any medium, provided the original work is properly cited. 
그리고 가치를 믿고 존중하고, 받아들이는 것을 포함한 한 개인의 가 치에 대한 전반적인 평가를 의미한다. ${ }^{9}$ 간호학과 학생들의 성희롱 피 해 경험 빈도와 자아존중감 간에는 반비례의 상관관계가 있다고 하 였다..$^{10}$ 또 다른 연구에서도 자존감이 낮은 청소년들이 높은 청소년 들 보다 더 비참한 성희롱을 경험한다고 보고하였다. 높은 자존감과 사회적 지지가 있는 청소년의 경우 성적 희롱을 처리하고 대처하는 것이 더 쉬우며, 정신 건강에 덜 해롭다. ${ }^{11}$ 상반되는 연구로는 높은 자 존감을 가진 여자청소년이 더 많은 성희롱을 경험한다고 하였고 또 한 심한 사회적 불안과 우울증 등 정신 건강에 해로운 영향을 미칠 수 있다고 지적하였다. ${ }^{12}$ 이와 같이 자아존중감이 높은 이들이 성희 롱을 당하는 위기상황에서 적극적으로 대처한다는 연구가 있는 반 면 반대로 자아존중감이 높은 여자청소년들이 주변사람들에게 더 많은 관심을 많이 받게 되고 성희롱도 더 많이 경험한다는 선행연구 도 있었다. 높은 자아존중감은 성희롱에 대한 인식과 대처 그리고 성 희롱 피해에 다양하게 작용하고 있음을 알 수 있다.

언급한 바와 같이 국내와 국외 모두 의료기관 내에서 다양하고 빈 번하게 성희롱이 발생하고 있고 이로 인한 폐해도 심각한 것을 알 수 있었다. 국내 물리치료분야에서도 상황은 크게 다르지 않으나 성희 롱과 관련된 연구는 거의 조사된 바가 없다. 따라서 본 연구는 물리치 료 전공 대학생의 자아존중감과 성희롱에 대한 인식 수준을 조사하 고 임상실습 현장에서 일어나는 성희롱의 유형과 피해 그리고 성희 롱 발생 시 어떤 방식으로 대처하였는지 알아보고자 한다.

\section{연구 방법}

\section{1. 연구대상}

연구의 표본집단은 경기, 충청에 소재하고 있는 물리치료(학)과에 재 학생이며 임상실습을 수행한 학생들이다. 연구에 대한 모든 설명을 듣고 내용을 이해하였으며, 자발적으로 참여하기로 동의한 대상자 들에 한하여 동의서를 받고 자기기입식으로 설문지를 작성하게 하였 다. 설문지는 240 부 수집되었으며, 불충분한 응답을 한 45 부를 제외 하고 195 부가 최종자료 분석에 포함되었다.

\section{2. 연구방법}

\section{1) 연구절차}

본 연구는 2018년 9월부터 11월까지 구조화된 설문지를 이용하여 자기 기입 방식으로 작성하도록 하였으며 작성된 후 그 자리에서 즉시 회수 하였다. 연구대상자의 권리를 고려하여 연구대상자에게 연구의 목적 과 내용을 설명하고 수집된 자료는 익명으로 처리되며 설문에 포함된 내용은 연구 외의 다른 목적으로는 사용되지 않음을 설명하였다. 본 연구에서 사용한 설문지의 구성은 대상자의 일반적 특성 7문항, 자아
존중감 25 문항, 성희롱 인식 10 문항, 임상실습 시 경험한 성희롱 유형 15 문항, 성희롱 피해 12 문항, 대처방안 20 문항으로 이루어져 있다.

\section{2) 측정도구}

(1) 자아존중감

자아존중감 문항은 '전혀 그렇지 않다.'의 1점에서 '아주 그렇다.의 4점 까지로 역산 문항은 역산처리하여 계산하였으며 점수가 높을수록 자아존중감의 수준이 높은 것을 의미한다. 자아존중감 측정 도구는 Coopersmith가 제작한 Self-Esteem Inventory를 ${ }^{13}$ 번역하여 사용한 것 으로 각 문항을 채점하기 쉽도록 부분 수정하였으며 신뢰도 $r=0.86$ 이다.14

\section{(2) 성희롱 인식}

성희롱에 대한 인식은 서울대학교 인권센터에서 활용하는 성희롱 인 식에 대한 자가진단테스트 10 개 문항으로 구성하였다. 각 문항에서 정답을 1 점, 오답을 0 점으로 하였고, 점수 범위는 최소 0 점에서 최고 10점이며 점수가 높을수록 인식이 높음을 의미한다.

\section{(3) 성희롱 유형과 피해}

성희롱 유형은 '있다', '없다' 로 응답을 하도록 하였고, 시각적. 신체적. 언어적 각각 5 문항씩 구성되었다. 성희롱 피해는 '있다', '없다' 로 응답 을 하도록 하였고, 정서적 6 문항, 신체적.사회적 부문은 각각 3 문항 씩 구성하였다. ${ }^{15}$

Table 1. General characteristics of subjects

$\mathrm{n}=195(\%)$

\begin{tabular}{llcc}
\hline 구분 & \multicolumn{1}{c}{ 특 성 } & 성희롱 경험 유 & 성희롱 경험 무 \\
\hline 성별 & 남 & $8(7.6)$ & $35(38.9)$ \\
& 여 & $97(92.4)$ & $55(61.1)$ \\
연령 & $20-22$ & $46(43.8)$ & $24(26.6)$ \\
& $23-25$ & $57(54.3)$ & $50(55.6)$ \\
& $26 \leq$ & $2(1.9)$ & $16(17.8)$ \\
학제 & 3년제 & $46(43.8)$ & $38(42.2)$ \\
& 4년제 & $59(56.2)$ & $52(57.8)$ \\
임상실습기간 & 4주 & - & $10(11.1)$ \\
& 8주 & $31(29.5)$ & $32(35.6)$ \\
& 12주 & $18(17.1)$ & $23(25.5)$ \\
& 16주 이상 & $56(53.3)$ & $25(27.8)$ \\
임상실습지역 & 서울· 경기 & $50(47.6)$ & $33(36.7)$ \\
& 대전 · 충청 & $55(52.4)$ & $57(63.3)$ \\
성희롱 예방교육 횟수 & 0회 & $5(4.7)$ & $1(1.1)$ \\
& 1회 & $9(8.6)$ & $8(8.9)$ \\
& 2회 & $22(21.0)$ & $23(25.6)$ \\
& 3회 이상 & $69(65.7)$ & $58(64.4)$ \\
& & 105 명 (100\%) & 90 명 (100\%) \\
\hline 전체 & & &
\end{tabular}


Table 2. Relationship between self-esteem and experience in sexual harassment

$(n=195)$

\begin{tabular}{|c|c|c|c|c|}
\hline 문항 & 그룹 & $\mathrm{M} \pm \mathrm{SD}$ & $\mathrm{t}$ & $\mathrm{p}$ \\
\hline \multirow[t]{2}{*}{ 1. 나는 내가 다른 사람이었으면 한 적이 없다. } & 유 & $2.46 \pm 0.86$ & -3.16 & $0.002^{* *}$ \\
\hline & 무 & $2.88 \pm 1.00$ & & \\
\hline \multirow[t]{2}{*}{ 2. 나는 여러 사람 앞에서 이야기하는 것이 어렵지 않다. } & 유 & $2.49 \pm 0.87$ & -3.354 & $0.001^{* *}$ \\
\hline & 무 & $2.89 \pm 0.80$ & & \\
\hline \multirow[t]{2}{*}{ 3. 나는 고쳐야 할 점이 없다. } & 유 & $1.69 \pm 0.73$ & -5.345 & $0.000^{* * *}$ \\
\hline & 무 & $2.29 \pm 0.85$ & & \\
\hline \multirow[t]{2}{*}{ 4. 나는 어렵지 않게 마음을 결정할 수 있다. } & 유 & $2.33 \pm 0.86$ & -3.773 & $0.000^{* * *}$ \\
\hline & 무 & $2.79 \pm 0.81$ & & \\
\hline \multirow[t]{2}{*}{ 5. 나는 새로운 것에 쉽게 익숙해지는 편이다. } & 유 & $2.61 \pm 0.69$ & -2.731 & $0.007^{*}$ \\
\hline & 무 & $2.89 \pm 0.74$ & & \\
\hline \multirow{2}{*}{ 6. 나는 매사에 쉽게 포기하지 않는 편이다. } & 유 & $2.59 \pm 0.62$ & -4.558 & $0.000^{\star * *}$ \\
\hline & 무 & $3.03 \pm 0.74$ & & \\
\hline \multirow[t]{2}{*}{ 7. 나는 남보다 행복한 편이다. } & 유 & $2.95 \pm 0.67$ & -2.802 & $0.006^{*}$ \\
\hline & 무 & $3.21 \pm 0.61$ & & \\
\hline \multirow[t]{2}{*}{ 8. 나는 나 자신에 대해 내세울 것이 많다고 생각한다. } & 유 & $2.65 \pm 0.65$ & -1.501 & 0.135 \\
\hline & 무 & $2.80 \pm 0.77$ & & \\
\hline \multirow[t]{2}{*}{ 9. 내가 하는 일은 뜻대로 된다. } & 유 & $2.56 \pm 0.66$ & -2.611 & $0.010^{*}$ \\
\hline & 무 & $2.82 \pm 0.73$ & & \\
\hline \multirow[t]{2}{*}{ 10. 다른 사람들에 비해 나는 사랑을 많이 받는 편이다. } & 유 & $2.92 \pm 0.74$ & -1.475 & 0.142 \\
\hline & 무 & $3.08 \pm 0.71$ & & \\
\hline \multirow[t]{2}{*}{ 11. 내가 하고 있는 일에 대해 항상 자부심을 느낀다. } & 유 & $2.84 \pm 0.64$ & -2.613 & $0.010^{*}$ \\
\hline & 무 & $3.08 \pm 0.64$ & & \\
\hline \multirow[t]{2}{*}{ 12. 나는 다른 사람이 나에게 의지해도 될 만큼 강하다. } & 유 & $2.65 \pm 0.76$ & -1.118 & 0.265 \\
\hline & 무 & $2.77 \pm 0.72$ & & \\
\hline \multirow[t]{2}{*}{ 13. 나는 내가 실패할 것 이라고 느끼고 있다. } & 유 & $3.27 \pm 0.74$ & 0.000 & 1.000 \\
\hline & 무 & $3.27 \pm 0.75$ & & \\
\hline \multirow[t]{2}{*}{ 14. 나는 다른 사람들과 재미있게 지낸다. } & 유 & $3.30 \pm 0.64$ & 0.185 & 0.853 \\
\hline & 무 & $3.29 \pm 0.55$ & & \\
\hline \multirow[t]{2}{*}{ 15. 나는 친구들과 잘 어울리며 인기가 있는 편이다. } & 유 & $2.91 \pm 0.61$ & -1.034 & 0.302 \\
\hline & 무 & $3.00 \pm 0.54$ & & \\
\hline \multirow[t]{2}{*}{ 16. 다른 사람들이 내 생각을 따라주는 편이다. } & 유 & $2.96 \pm 0.50$ & -0.067 & 0.946 \\
\hline & 무 & $2.94 \pm 0.49$ & & \\
\hline \multirow[t]{2}{*}{ 17. 나는 다른 사람들과 함께하고 싶지 않다. } & 유 & $3.36 \pm 0.81$ & -0.446 & 0.656 \\
\hline & 무 & $3.31 \pm 0.77$ & & \\
\hline \multirow[t]{2}{*}{ 18. 다른 사람들은 나를 자주 괴롭힌다. } & 유 & $3.49 \pm 0.71$ & -0.459 & 0.647 \\
\hline & 무 & $3.53 \pm 0.74$ & & \\
\hline \multirow[t]{2}{*}{ 19. 나는 할 말이 있을 때 그 말을 하는 편이다. } & 유 & $2.85 \pm 0.72$ & -2.323 & $0.021^{*}$ \\
\hline & 무 & $3.09 \pm 0.73$ & & \\
\hline \multirow[t]{2}{*}{ 20. 가족 중에 나에게 관심을 보여주는 사람이 있다. } & 유 & $3.58 \pm 0.72$ & 1.008 & 0.315 \\
\hline & 무 & $3.49 \pm 0.53$ & & \\
\hline 21. 우리 가족은 나에게 지나친 기대를 하지 않는다. & 유 & $2.89 \pm 0.99$ & -0.194 & 0.846 \\
\hline & 무 & $2.91 \pm 0.80$ & & \\
\hline 22. 우리가족은 내 기분을 잘 이해해주는 편이다. & 유 & $2.92 \pm 0.91$ & -2.117 & $0.035^{*}$ \\
\hline & 무 & $3.18 \pm 0.74$ & & \\
\hline 23. 집을 나가버리고 싶다는 생각을 해본 적이 없다. & 유 & $2.36 \pm 1.01$ & -1.899 & 0.059 \\
\hline & 무 & $2.63 \pm 0.98$ & & \\
\hline 24. 우리 가족들이 나를 잘 이해하고 있다. & 유 & $2.97 \pm 0.82$ & -2.231 & $0.027^{*}$ \\
\hline & 무 & $3.21 \pm 0.68$ & & \\
\hline 25. 가족들이 나를 미워하는 것 같지는 않다. & 유 & $3.57 \pm 0.77$ & -0.609 & 0.543 \\
\hline & 무 & $3.63 \pm 0.63$ & & \\
\hline 평균 & 유 & $71.17 \pm 18.65$ & - & \\
\hline & 무 & $76.03 \pm 18.03$ & & \\
\hline
\end{tabular}

Mean \pm Standard deviation, Yoo: A group that has experienced sexual harassment. Mu: A group that has not experienced sexual harassment, *Significant difference between groups $(p<0.05)$; **Significant difference between groups $(p<0.01)$; ${ }^{* * *}$ Significant difference between groups $(p<0.001)$. 
(4) 대처방안

대처방안은 20 문항 중 자신이 대처한 혹은 대처 할 방안을 대상자가 1 순위부터 3순위까지 순위를 선택하도록 하였다. 성희롱에 관한 대 처를 측정한 연구 도구를 기반으로 회피, 완화, 조정, 직면의 4 가지 대 처 유형에 해당되는 문항으로 추출하여 도구를 구성하였다. ${ }^{16}$

\section{3) 자료분석}

대상자의 일반적 특성과 성희롱 인식, 실태, 피해 및 대처방안은 기술 통계를 활용하였고, 자아존중감은 문항의 점수 합과 평균을 구하였 다. 성희롱 경험에 따른 자아존중감 및 성희롱 인식에 대한 분석은 독 립 t검정을 실시하였다. 자료의 분석은 SPSS ver. 22.0 프로그램을 이용 하여 통계분석 하였으며, 유의수준은 $\mathrm{p}<0.05$ 로 하였다.

\section{결 과}

\section{1. 대상자의 일반적 특성}

대상자의 일반적 특성은 Tablel과 같다. 195명 중 임상실습 시 성희롱 을 경험한 대상자는 105 명이였고 $92.4 \%$ 가 여학생이었다. 전체 대상자 중 $97 \%$ 는 1회 이상 성희롱 예방교육을 받았다.

Table 3. Sexual harassment in clinical placement

\begin{tabular}{llc}
\hline 성희롱 유형 & \multicolumn{1}{c}{ 문항(다중 응답) } & 성희롱 경험 유 \\
\hline 시각적 & 1. 외설적이고 성적인 낙서 & $8(7.6)$ \\
성희롱 & 2. 연예인 누드사진이나 동영상을 보여주는 것 & $2(1.9)$ \\
& 3. 인터넷음란사이트를 보거나 보여주는 것 & $1(1.0)$ \\
& 4. 특정인을 지속적으로 뜷어지게 빤히 보는 것 & $64(61.0)$ \\
& 5. 상대방의 특정신체부위를 유심히 쳐다보거나 흩어 & $46(43.8)$ \\
& 보는 것 & \\
& 합계 & $121(60.04)$ \\
1. 자신의 특정신체부위를 만지거나 노출시키는 것 & $14(13.3)$ \\
신체적 & 2. 웡하하지 않는데도 상대방의 신체를 툭툭 치거나 꼬 & $43(41.0)$ \\
& 집는 것 & \\
& 3. 의도적으로 몸을 스치고 지나가는 것 & $19(18.1)$ \\
& 4. 몸을 겨안거나 밀착시키는 것 & $13(12.4)$ \\
& 5. 신체부위를 만지는 행위 & $31(29.5)$ \\
& 합계 & $120(114.30)$ \\
& 1. 외모에 대한 비유나 품평 & $92(87.6)$ \\
& 2. 섹시하다는 표현 & $14(13.3)$ \\
3. 음담패설 & $5(23.8)$ \\
4. 자신의 사생활이나 성적 경험을 공개적으로 말하 & $24(22.9)$ \\
언어적 & 는 것 & \\
성희롱 & 5. 상대의 신체 특성과 관련된 별명을 만들어 부르는 것 & $23(21.9)$ \\
& 합계 합계 & $158(169.8)$ \\
& & $399(344.14)$ \\
\hline & &
\end{tabular}

Multiple response available, percent calculated without missing.

\section{2. 자아존중감과 성희롱 피해경험의 관련성}

성희롱 피해경험이 있는 그룹의 자아존중감은 100 점 만점에 평균 71.17점이고, 성희롱 피해경험이 없는 학생들의 자아존중감은 평균 76.03점으로 평균값의 차이가 있었다(Table 2).

\section{3. 성희롱에 대한 인식과 성희롱 피해경험의 관련성}

성희롱 인식을 묻는 10 문항에 대한 정답률은 성희롱 경험이 있는 그 룹은 $86.18 \pm 6.04$ 점이고 성희롱 경험이 없는 그룹은 $87.35 \pm 14.60$ 점으 로 두 그룹간에 유의한 차이는 없었다. 두 그룹 모두 높은 정답률은 높았으나 9번 문항과 "사무실에서 통신으로 음란사이트를 혼자 보고 있는데 다른 사람이 이를 우연히 보았다면 이것도 성희롱에 해당될 수 있다"와 10 번 문항 “성희롱은 남녀 차별의 한 형태이다” 에서 두 그 룹 모두 낮은 인식수준을 나타내었다.

\section{4. 성희롱 유형}

성희롱 피해경험이 있는 105 명에게 어떤 유형의 성희롱을 경험하였는 지 조사하였다. 언어적 성희롱은 ‘외모에 대한 비유나 품평' $(87.6 \%)$ 이 가장 많았고, 시각적 성희롱은 '특정인을 지속적으로 뚫어지게 빤히 보는 것'(61.0\%), 신체적 성희롱은 ‘원하지 않는데도 상대방의 신체를 툭툭 치거나 꼬집는 것'(41.0\%)이 가장 많았다고 응답하였다(Table 3).

\section{5. 성희롱 피해}

성희롱 피해자에게 미치는 영향에서 다중응답으로 분석한 결과 성 희롱을 경험한 대상자는 '모욕감 및 당혹감' '자존심 손상', '수치심'

Table 4. Emotional, physical and social damage from sexual harassment $n=105(\%)$

\begin{tabular}{llc}
\hline 성희롱의 피해 유형 & \multicolumn{1}{c}{ 문항(다중 응답) } & 성희롱 경험 유 \\
\hline 정서적 피해 & 1. 수치심 & $78(74.3)$ \\
& 2. 자존심 손상 & $83(79.0)$ \\
& 3. 모욕감, 당혹감 & $86(81.9)$ \\
& 4. 분노감 & $75(71.4)$ \\
& 5. 불안감, 두려움, 공포 & $54(51.4)$ \\
& 6. 걱정, 우울증 & $48(45.7)$ \\
& 합계 & $424(403.7)$ \\
신체적 피해 & 1. 불면증 & $39(37.1)$ \\
& 2. 두통 & $35(33.3)$ \\
& 3. 위장장애, 메스꺼움, 식욕감퇴 & $39(37.1)$ \\
& 합계 & $113(107.5)$ \\
사회적 피해 & 1. 사기 및 능률 저하 & $59(56.2)$ \\
& 2. 임상실습 다니기 싷어 짐 & $71(67.6)$ \\
& 3. 학교를 그만두고 싶어 짐 & $24(22.9)$ \\
& 합계 & $154(146.7)$ \\
& & $691(657.9)$ \\
\hline 전체 합계 & &
\end{tabular}

Multiple response available, percent calculated without missing. 
Table 5. Measures to cope with sexual harassment

$n=195(\%)$

\begin{tabular}{|c|c|c|c|c|c|}
\hline 대처방안 & & 그룹 & 1순위 & 2순위 & 3순위 \\
\hline \multirow[t]{14}{*}{ 회피 } & \multirow[t]{2}{*}{ 1. 별다른 조치를 취하지 않는다. } & 유 & $0(-)$ & $28(4.8)$ & $17(2.9)$ \\
\hline & & 무 & $6(1.1)$ & $0(-)$ & $0(-)$ \\
\hline & \multirow[t]{2}{*}{ 2. 모르는 척 하거나 슬쩍 자리를 피한다. } & 유 & $50(8.6)$ & $22(3.8)$ & $44(7.6)$ \\
\hline & & 무 & $0(-)$ & $6(1.1)$ & $13(2.2)$ \\
\hline & \multirow[t]{2}{*}{ 3. 대꾸나 표정 등 반응을 보이지 않고 무관심한 듯이 행동한다. } & 유 & $67(11.4)$ & $39(6.7)$ & $50(8.6)$ \\
\hline & & 무 & $46(7.8)$ & $6(1.1)$ & $13(2.2)$ \\
\hline & \multirow[t]{2}{*}{ 4. 가해자가 이상한 눈으로 쳐다보거나 신체의 일부를 응시할 때 무심히 대한다. } & 유 & $11(1.9)$ & $33(5.7)$ & $33(5.7)$ \\
\hline & & 무 & $13(2.2)$ & $0(-)$ & $13(2.2)$ \\
\hline & \multirow[t]{2}{*}{ 5. 다음날 바로 출근하지 않고 퇴사한다 } & 유 & $0(-)$ & $0(-)$ & $6(1.0)$ \\
\hline & & 무 & $6(1.1)$ & $0(-)$ & $19(3.3)$ \\
\hline & \multirow[t]{2}{*}{ 6. 성희롱 유발 할 가능성이 있는 사람이나 상황은 미리 피한다. } & 유 & $84(14.3)$ & $33(5.7)$ & $28(4.8)$ \\
\hline & & 무 & $46(7.8)$ & $19(3.3)$ & $0(-)$ \\
\hline & \multirow[t]{2}{*}{ 합계 } & 유 & $212(36.2)$ & $156(26.7)$ & $179(30.6)$ \\
\hline & & 무 & $117(20)$ & $32(5.5)$ & $58(9.9)$ \\
\hline \multirow[t]{12}{*}{ 완화 } & \multirow[t]{2}{*}{ 7. 농담으로 웃어넘기거나 분위기를 동조하는 척 한다. } & 유 & $39(6.7)$ & $33(5.7)$ & $6(1.0)$ \\
\hline & & 무 & $0(-)$ & $6(1.1)$ & $13(2.2)$ \\
\hline & \multirow[t]{2}{*}{ 8. 대범하게 보이기 위해 무시하거나 한술 더 떠서 장단을 맞추어 준다. } & 유 & $11(1.9)$ & $17(2.9)$ & $22(3.8)$ \\
\hline & & 무 & $0(-)$ & $0(-)$ & $13(2.2)$ \\
\hline & \multirow[t]{2}{*}{ 9. 직장 내 다른 동료와 이야기하며 가해자를 몰래 비난한다. } & 유 & $6(1.0)$ & $50(8.6)$ & $28(4.8)$ \\
\hline & & 무 & $0(-)$ & $19(3.3)$ & $6(1.1)$ \\
\hline & \multirow[t]{2}{*}{ 10. 자신의 옷이나 외모에 대한 칭찬으로 받아들인다. } & 유 & $0(-)$ & $6(1.0)$ & $6(1.0)$ \\
\hline & & 무 & $13(2.2)$ & $6(1.1)$ & $0(-)$ \\
\hline & \multirow[t]{2}{*}{ 11. 자신에게 접근하려는 호감의 표현으로 받아들인다. } & 유 & $0(-)$ & $0(-)$ & $6(1.0)$ \\
\hline & & 무 & $0(-)$ & $6(1.1)$ & $0(-)$ \\
\hline & \multirow[t]{2}{*}{ 합계 } & 유 & $56(9.6)$ & $106(18.2)$ & $179(11.6)$ \\
\hline & & 무 & $13(2.2)$ & $39(6.6)$ & $32(5.5)$ \\
\hline \multirow[t]{8}{*}{ 조정 } & \multirow[t]{2}{*}{ 12. 불쾌하다는 표정이나 행동적 암시로 상대가 알게 한다. } & 유 & $128(21.9)$ & $84(14.3)$ & $78(13.3)$ \\
\hline & & 무 & $117(20.0)$ & $123(21.1)$ & $33(5.6)$ \\
\hline & \multirow[t]{2}{*}{ 13. 관련 사이트에 글을 올려 상담을 받는다. } & 유 & $6(1.0)$ & $0(-)$ & 1 \\
\hline & & 무 & $6(1.1)$ & $0(-)$ & 5.6 \\
\hline & \multirow[t]{2}{*}{ 14. 환자를 대상으로 성희롱 예방교육을 실시하도록 요구한다. } & 유 & $6(1.0)$ & $33(5.7)$ & $33(5.7)$ \\
\hline & & 무 & $0(-)$ & $33(5.6)$ & $19(3.3)$ \\
\hline & \multirow[t]{2}{*}{ 합계 } & 유 & $140(23.9)$ & $117(20.0)$ & $117(20.0)$ \\
\hline & & 무 & $123(21.1)$ & $156(26.7)$ & $85(14.5)$ \\
\hline \multirow[t]{14}{*}{ 직면 } & 15. 불쾌하다고 직접 말하고 사과를 요구한다. & 유 & $44(7.6)$ & $44(7.6)$ & $67(11.4)$ \\
\hline & & 무 & $150(25.6)$ & $123(21.1)$ & $71(12.2)$ \\
\hline & 16. 관련기관(여성단체, 노동부, 지방노동행정기관, 경찰, 국가인권위원회)에 신고한다. & 유 & $33(5.7)$ & $50(8.6)$ & $67(11.4)$ \\
\hline & & 무 & $59(10.0)$ & $52(8.9)$ & $123(21.1)$ \\
\hline & 17. 증거가 될 만한 자료를 남긴다. & 유 & $56(9.5)$ & $59(10.0)$ & $44(7.6)$ \\
\hline & & 무 & $104(17.8)$ & $111(18.9)$ & $78(13.3)$ \\
\hline & 18. 가해자에게 성희롱 중단을 요구하는 경고 편지나 문자를 보낸다. & 유 & $0(-)$ & $6(1.0)$ & $6(1.0)$ \\
\hline & & 무 & $0(-)$ & $13(2.2)$ & $0(-)$ \\
\hline & 19. 강하게 중단 할 것을 요구하거나 물리적 공격을 취한다. & 유 & $39(6.7)$ & $11(1.9)$ & $22(3.8)$ \\
\hline & & 무 & $6(1.1)$ & $26(4.4)$ & $71(12.2)$ \\
\hline & 20. 환자가족들에게 성희롱 중단 요청을 한다. & 유 & $6(1.0)$ & $33(5.7)$ & $17(2.9)$ \\
\hline & & 무 & $6(1.1)$ & $33(5.6)$ & $65(11.1)$ \\
\hline & 합계 & 유 & $178(30.5)$ & $204(34.8)$ & $223(38.1)$ \\
\hline & & 무 & $325(55.6)$ & $357(61.1)$ & 409 (69.9) \\
\hline 총합계 & & 유 & $586(5.0)$ & $583(5.0)$ & $587(5.0)$ \\
\hline & & 무 & $579(4.9)$ & $584(5.0)$ & $584(5.0)$ \\
\hline
\end{tabular}

Multiple response available, Among the measures to cope with membership fees, mitigation, Coordination, and confrontations, the company selects the countermeasures it wishes to take as the first, second, and third priority. 
등 주로 정서적 피해의 심각성을 알수 있었다(Table 4).

\section{6. 대처방안}

대처방안은 모두 20 문항으로 구성되어 있고 회피, 완화, 조정, 직면으 로 구분되어 있다. 성희롱에 노출되었을 때 자신이 어떻게 대처했는지 또는 대처할지를 묻는 질문으로 1 순위, 2 순위, 3 순위를 선택하도록 선 정하였다. 성희롱을 경험한 그룹은 경험하지 않은 그룹과 비교하여 회 피의 비율이 높게 나타났다. 반면 성희롱을 경험하지 않은 그룹에서 는 직면의 대처방법에 높은 비율을 나타내었다. 즉 의식적으로는 직면 의 대처방법을 선택해야 한다고 생각하지만 실제적인 성희롱 상황에 서는 주로 회피 반응을 나타낸다는 것을 알 수 있다(Table 5).

\section{고 찰}

연구결과 임상실습 시 성희롱을 경험한 대상자는 설문 응답자의 $53.8 \%$ 로 나타났다. 물리치료사와 물리치료 대학생을 대상으로 한 국 외 연구에서도 $80.9 \%$ 이상이 성희롱 피해를 경험했다는 결과와 유사 하다. ${ }^{4}$ 이와 같이 보건의료 인력의 상당수가 성희롱을 경험하였고, 타 직종 보다 상대적으로 성희롱 경험 비율이 높게 나타났다. ${ }^{7}$ 자아존 중감과의 관련성을 살펴본 결과 성희롱 피해경험이 있는 그룹은 평 균 71.17점이고 성희롱 피해경험이 없는 그룹은 76.03점으로 나타났 다. 자아존중감 설문지는 가정의 지지와 사회적 지지 정도를 반영한 설문지이다. 25 문항 중 12 문항은 성희롱을 경험한 그룹과 경험하지 않은 그룹에서 유의한 차이가 있는 것을 알 수 있었다. 자아존중감이 높을수록 불합리한 대우에 대하여 회피하며 문제를 키우기 보다는 직면의 태도로 초기대응 함으로서 정신적 또는 신체적 측면에서 자 신을 보호 할 수 있을 것이다. 선행연구에서 언급한 바와 같이, 자아 존중감과 사회적 지지가 낮을수록 더 비참한 성희롱에 노출되고 그 에 따른 피해 또한 심각하다고 하였다." 특히 여자청소년들의 경우 심 한 사회적 불안과 우울증 등 정신 건강에 해로운 영향을 받을 수 있 다고 지적하였다. ${ }^{2}$ 이렇듯 자아존중감은 성희롱과의 관련성 뿐만 아 니라 직무수행 과정에도 영향을 미친다는 연구가 있다. 물리치료사 의 자아존중감과 직무스트레스의 상관관계에 관한 연구에 따르면 자아존중감이 높을수록 심리적 직무스트레스를 적게 받는 것으로 나타났다. ${ }^{18}$ 자아존중감은 성희롱의 인식과 대처방법, 또는 정신적, 신 체적 피해를 인식하는데 있어서도 폭넓게 영향을 미치고 있으며 더 나아가 직무스트레스에서도 양의 상관관계를 나타내고 있다. 자존 감 형성을 강조하는 사회감정 프로그램은 피해발생 가능성을 줄이 고 발생시 해로운 영향을 줄이는데 도움이 될 수 있다고 사료된다. 따 라서 자존감을 형성하고 강화할 수 있도록 다양한 방법에 대하여 관 심을 가져야 할 것이다. 피해경험을 유형별로 보았을 때, 언어적성희
롱이 가장 두드러지게 높았으며 그 다음 시각적, 신체적성희롱 순으 로 조사되었다. 여성 작업치료사들을 대상으로 조사한 성희롱 유형 에서도 언어적 성희롱이 $71.4 \%$ 로 가장 높았고, 신체적. 시각적성희롱 이 48.6\%로 본 연구결과와 유사하게 나타났다. ${ }^{19}$ 사무직과 같은 타 직 종과 비교하여 언어적 성희롱이 가장 빈번하게 일어나고 있는 이유 는 치료사의 업무로서 환자의 자세나 체형을 관찰하고 평가하며 치 료 교육하는 업무에 익숙하여 가해자도 성희롱이라고 인식하지 못 한 상태에서 언어적 성희롱이 일어나고 있다. 언어적 성희롱은 실습 기관의 물리치료사나 환자가 실습학생에게 동의를 구하지 않고 자세 나체형 또는 외모에 대한 품평을 하면서 일어나는 경우가 많다. 상대 방의 외모에 대한 품평이 언어적 성희롱이라고 전혀 인식하지 못하 고 있기 때문에 이러한 실수가 계속 일어나고 있는 것이다. 성희롱 발 생 시 대처방법에 관한 질문에 성희롱을 경험한 그룹에서는 상대적 으로 회피의 비율이 높고, 성희롱을 경험하지 않은 그룹에서는 직면 의 대처방법에 높은 선택 비율을 나타내었다. 성희롱에 대해 알고도 모르는 척하거나 거부의사를 밝히지 못하고 소극적으로 대처하는 경우가 많다고 이미 보고 하였다. ${ }^{20}$ 일반적으로 성희롱 피해를 경험했 을 때 적극적으로 대처할 것이라는 생각과 다르게 실제 성희롱 피해 상황에서 피해자가 소극적으로 대처하는 경향이 있다. 가해자의 부 당한 언행을 지적하고 바로 잡을 수 있도록 사회구성원들의 지지가 더욱 필요하다고 생각된다. ${ }^{21}$ 언어적 성희롱의 발생빈도가 유의하게 높았고 피해유형으로 정서적 피해가 가장 심각함을 알 수 있었다. 이 상의 결과로 임상실습 환경에서 발생되는 성희롱의 유형과 피해유형 그리고 어떻게 대처하고 있는지 확인하였다. 현재 성희롱교육보다 더 구체적이고 병원 상황에 맞는 현실적인 성희롱 예방교육이나 대처방 법들을 교육하여, 실제 상황에서 더 적극적으로 대처할 수 있도록 해 야 할 것이다. 병원 상황에 맞는 현실적인 성희롱 예방교육을 위해서 는 지속적으로 어떤 형태의 성희롱이 일어나고 있는지 병원 자체적 으로 익명의 온라인 설문방식으로 조사가 정기적으로 실시되어야 할 것이며 이것을 기반으로 공감할 수 있는 현실적인 예방교육이 이루 어져야 할 것이다. 그리고 성희롱 예방교육은 환자, 보호자, 그리고 보 건의료인들을 대상으로 확대하여 지속적이고 정기적으로 실시할 것 을 제언한다. 뿐만 아니라 성희롱과 관련하여 직장 내에서 불미스러 운 일이 발생했을 때 피해자를 우선적으로 보호하고 지지하여 회피 하지 않고 직면하여 함께 해결하고 예방할 수 있도록 사회적 지지가 보완되어야 할 것이다. 본 연구의 제한점은 대상자의 수가 적고 경기 와 충청 지역에 국한되어 있어 국내 임상현장 전체를 반영하기에는 한계가 있으며, 개인적인 공간에서 진솔한 답변을 할 수 있도록 온라 인 설문방식을 활용하는 추가적인 연구가 진행되어야 할 것이다. 


\section{ACKNOWLEDGEMENTS}

This study was supported by an academic research fund (a special research project) from the Healthcare Science Research Institute of Cheongju University (academic year 2018-2019).

\section{REFERENCES}

1. Yoon HJ. A study on the reformation of sexual harassment remedy system in the workplace. Ewha Womans University, Dissertation of Master' s Degree. 2010.

2. Koh JH. The recognition, experience and related factors about sexual harrassment in the workplace of hospital nurses. Dong-a University, Dissertation of Master's Degree. 2013.

3. deMayo RA. Patient sexual behaviors and sexual harassment: a national survey of physical therapists. Phys Ther. 1997;77(7):739-44.

4. McComas J, Hébert C, Giacomin C, et al. Experiences of student and practicing physical therapists with inappropriate patient sexual behavior. Phys Ther. 1993;73(11):762-9.

5. Arulogun OS, Omotosho IK, Titiloye MA. Experience of sexual harassment and coping strategies among students of the school of nursing of a tertiary hospital in southwest nigeria. International J Nurs Midwifery. 2013;5(4):70-5.

6. Ferns T, Meerabeau L. Verbal abuse experienced by nursing students. J Adv Nurs. 2008;61(4):436-44.

7. Celik Y, Celik SS. Sexual Harassment Against Nurses in Turkey. J Nurs Scholarsh. 2007;39(2):200-6.

8. Mitchell KJ, Ybarra ML, Korchmaros JD. Sexual harassment among adolescents of different sexual orientations and gender identities. Child Abuse Negl. 2014;38(2): 280-95.

9. Mann M, Hosman CMH, Schaalma Hp, de Vries NK. Self-esteem in a broad-spectrum approach for mental health promotion. Health Educ Res. 2004;19(4):357-72.

10. Kim TI, Kwon YJ, kim MJ. Experience and perception of sexual harassment during the clinical practice and self-esteem among nursing students. Korean J Women Health Nurs. 2017;23(1):21-32.

11. Mitchell KJ, Ybarra ML, Korchmaros JD. Sexual harassment among adolescents of different sexual orientations and gender identities. Child Abuse Negl. 2014;38(2):280-95.

12. Apell S, Marttunen M, Frojd S, Kaltiala R. Experiences of sexual harassment are associated with high self-esteem and social anxiety among adolescent girls. Nord J Psychiatry. 2019;73(6):365-71.

13. Coopersmith S. Self-esteem inventory. Self-Esteem Institute. 1967.

14. Kang JG. The influence of self-conceptualization, moderation, and academic achievement on the level of career aspect. Seoul University. Dissertation of Master's Degree. 1986.

15. Kim YY. The perception and actual experiences of sexual harassment among nursing college students. Kyungpook University, Dissertation of Master's Degree. 2014.

16. Maypole, D. Sexual harassment of social workers at work: Injustice within. J Soc work. 1986; 31(1), 29-34.

17. Kim SJ. Awareness levels and influencing factors of sexual harassment among dental hygiene students. JKCA. 2015;15(2):352-62.

18. Ro HL. Relationship between job stress and Self-esteem of physical therapists. J Kor Soc Phys Ther. 2010;22(1):83-90.

19. Lee JH, Song YW, Cha TH. A study on job stress and working environment of female occupational therapist. J Korea Acad Industr Coop Soc. 2017;18(2):484-92.

20. Moon HK. Effects of education program on preventing sexual harassment for college students. Sangmyung University, Dissertation of Doctorate Degree. 2009.

21. Ha HS. Sexual harassment coping style of university students. Korea J Counsel Psychotherapy. 2007;19(3):785-800 